\title{
Does Federalism Reduce Ethnic Conflict? Evidence From the Ethiopian Experience
}

\author{
Zerihun Berhane* and Samuel Tefera $^{\dagger}$
}

\begin{abstract}
This paper discusses the issue of federalism and conflicts in Ethiopia by posing the question: to what extent does the current system of ethnic Federalism help to reduce ethnic tensions and conflicts? Although federalism is taken by many as a typical strategy for avoiding ethnic conflict and promoting democracy in multiethnic societies, the Ethiopian experience largely suggest that the system is not reducing ethnic tensions and conflicts. Ethnicity being the major organizing principle of the federal system in the country, promotes conflicts stressing the primordial notions of ethnicity and mobilization. It has encouraged differences and competition over the control of power and resources at a local level. Thus, conflicts are increasing, becoming more decentralized and protracted. These suggest that in the Ethiopian context, there is a need to move away from using ethnicity as a sole criterion and to organize the federation using geographical and economic considerations. This would further help to reduce the current ethnic strife by encouraging civic nationality and trust among people.
\end{abstract}

Keywords: Conflict, Ethnicity, Federalism, Ethiopia

DOI: https://dx.doi.org/10.4314/ejossah.v14i1.5

${ }^{*}$ Corresponding Author: Assistant Professor, Center for African and Oriental Studies, Addis Ababa University, Email: zerihunb2006@gmail.com, Tel:+251911963305, P.O BOX: 1176/ Addis Ababa

${ }^{+}$Assistant Professor, Center for African and Oriental Studies, Addis Ababa University, Email: samuelteferaalemu1983@gmail.com, Tel: +251947742183, P.O.BOX: 1176/ Addis Ababa

This work is licensed to the publisher under the Creative Commons Attribution-NonCommercialNoDerivs License. 


\section{Introduction}

Federalism began to be considered as a useful tool of state/ nation building after the end of the Second World War (Watts, 1994 and 2001). Thus, several countries in Africa and Asia espoused this system after gaining independence as a means of catering for competing and conflicting aspirations for autonomy within their territories. Examples of such countries include India, Nigeria and Malaysia (Rothchild, 1966: 275-93).

Federalism has long been considered as a system that offers a feasible means of integrating the interests of larger political entities, which are capable of promoting economic development and maintaining security, versus smaller political units which tend to be responsible to their own constituents and local interests (Watts, 1994). The system achieves this by establishing a government where power is shared between local and central units along with the lines of constitutionally established duties and responsibilities for each body of the government. However, the same system can also help to create and sustain conflicts that may threaten the existence of the polity. Jan Erk and Lawrence Anderson in their discussion of this paradoxical tendency of federalism recognized that "federalism has both secession inducing and secession preventing" characteristics (Erk and Anderson, 2009:192).

Current debates on federalism, can be traced back to the $18^{\text {th }}$ century, and are largely shaped by two major developments that came after the end of the cold war and led to contrasting views on the desirability and success of federalism (Burgess, 2006 and McGarry, 2005: 15). The first of these developments corresponds to the fall and dissolution of the USSR and the then European federations of Yugoslavia and Czechoslovakia which largely reinforced the doubts about the stability and the durability of multi-ethnic federations (McGarry, 2005:15). Moreover, the secessionist sentiment in Canada's Quebec state and the Belgian linguistically-based federation added impetus to such skepticism. The second event has to do with the reconstitution of multi-ethnic nations through federalism as a political strategy adopted by a number of governments following the collapse of authoritarian regimes. An example of such developments is the ethnic federalism in Ethiopia along with other countries such as the Russian Federation, Bosnia-Herzegovina and more recently Iraq (Roeder, 2009: 03-19).

The purpose of this article is to critically assess the nature of federalism in Ethiopia particularly in terms of its implications for inter-ethnic relations in the country. The main question posed in this article is therefore: To what extent does the current system of Ethnic Federalism help to reduce ethnic tensions and conflicts? This question is imperative given the fact that concerns for peace and stability override any development efforts or achievements in multi-ethnic nations like 
Ethiopia. As observed elsewhere, achieving a certain level of development is not always a guarantee for not falling back into anarchy and endless conflicts (e.g. Somalia, Ivory Coast). Ethiopia presents an interesting case to examine how federalism works in multi-ethnic states. Ethiopia ranks $20^{\text {th }}$ out of 60 countries designated as failed states by the Foreign Policy magazine (See the Failed States Index 2011 at Foreign Policy, 2011) and in a recent Fragile States Index of 2018 Ethiopia was ranked $15^{\text {th }}$ out of 178 countries (The Fund For Peace [FFP], 2018). What is alarming from these reports is that the country scored high on 'factionalized elites' and 'group grievances' as indicators of failing states. These same indictors can also hint the mounting ethnic tension in the country. Thus, examining how federalism as a political system, manages conflicts is crucial since ethnic diversity should be judiciously managed by a system of governance that ensures balanced political representation, respect for human rights as well as democracy that are vital for promoting development.

Previous studies on Ethiopian federalism are overwhelmingly focused on specific case studies. Some of these studies discuss the nature of Ethiopian federalism in relation to ethnic identity and its problems (Asnake, $2009 \& 2010$ ). Other studies point out to the problem of managing territorially dispersed diversity in ethnically-based boundaries of regional states (Van der Beken, 2010: 1-30) and ethnic decentralization and inclusive governance in multi-ethnic cities such as Dire Dawa (Asnake, 2014: 589-605). Still other studies examine the role of the secessionist clause in the constitution and its implications for the stability of a multi-ethnic state (Habtu, 2005: 313-35). All these studies do not provide a holistic picture of the federal system and its effects on either reducing or exacerbating conflicts in Ethiopia except for some studies that, albeit descriptively, shed light on the relationship between ethnic federalism ethnic-based conflicts (Aalen, 2002; Abbink, 2011: 596-618; Assefa, 2012: 435-73). Thus, this paper aims to complement these few studies by using a combination of case studies and analysis of longitudinal data obtained from conflict data sets particularly the Armed Conflict Location and Event Data Project (ACLED) to provide a rigorous and fresh evidence on the topic.

The remainder of this article is organized into four sections. Section two provides an overview of federalism in Ethiopia along with its origins and its main features. Section three discusses the concept of ethnicity and looks into the theories of ethnic conflict laying the ground for the subsequent discussion. The next section examines the trends in ethnic conflict in Ethiopia and presents a review of the empirical observations on the subject. The final section provides concluding remarks based on the dominant themes that stand out from the discussions. 


\section{The Federal System in Ethiopia Background}

Ethiopia is a country with a long history of statehood in Africa that could be traced back to the ancient Aksumite kingdom that emerged as early as $400 \mathrm{BC}$. It is a nation that was never colonized by a foreign power and kept its independence. However, in its long history, Ethiopia's move towards a modern nation state could be associated with the time of Emperor Theodores II from 1885 to 1868 through his land reforms, organization of national army and other modernization efforts that gained momentum and consolidated during the reign of Emperor Menelik II (1889-1913) and Emperor Haileselasse I (1930-1974) (Bahru, 1991 and Henze, 2000).

In 1974, a committee of disgruntled military officers (Derg) staged a coup and took power by deposing the emperor. This set the stage for some sweeping changes as the Derg adopted socialism as its political ideology, abolished feudalism and nationalized land in 1975. The same year, the Tigray People's Liberation Front (TPLF) started its armed struggle and joined the Eritrean People's Liberation Front in the northern provinces of the country. In May 1991, the Derg was ousted from power and the TPLF led coalition of ethno-nationalist organizations under the name Ethiopian People's Revolutionary Democratic Front (EPRDF) controlled the central government (Markakis, 1974; Messay, 2011). The EPRDF was established in 1989 by TPLF, EPDM (Ethiopian Peoples' Democratic Movement) later it was restructured to Amhara National Democratic Movement (ANDM), OPDO (Oromo People's Democratic Organization), and SPDRF (Southern People's Democratic Revolutionary Movement).

EPRDF's rise to power was followed by major changes in the country's national politics. A transitional government was established led by EPRDF and its affiliates that were organized on ethnic bases. These groups participated in the ratification of the 1991 Transitional Charter that recognized Eritrea's secession, gave self-determination rights to up to and including secession the various ethnic groups and endorsed multiparty democracy with political and civil liberties. The 1995 constitution established a federation of nine states, created mainly on the basis of ethno-linguistic criterion along with the contentious clause on the right of secession (ICG, 2009 and Asnake, 2014). The constitution also established a bicameral parliamentary system with the House of People's Representatives elected directly every five years and the House of Federation with representatives from the countries different nationalities (Tesfaye, 2002). The term nations and nationalities is officially used by the state following Stalinist dictates on the question of nationalities instead of using the term ethnic groups. Such a discourse seems to ignore the historical intermingling and centuries-old interaction between the 
various ethnic groups in the country that have implications for supra-ethnic nationality.

\section{Ethnic Federalism in Ethiopia: Origin and Features}

Ethnic federalism was officially adopted by the government as a means of keeping the unity of the nation as there were secessionist movements guided by ethnically mobilized political organizations that intensified after the fall of the centralized regime (Ibid). However, the reconfiguration of the state's politics along ethnic lines seems to originate from the ideological motivation of the TPLF leaders that were inspired by Stalin's concepts of nationalities and self-determination and used them as tools to mobilize support for their struggle against the military regime (Aalen, 2002). Thus, this led to the formalization of ethnicity as a basic principle of state organization, and political representation.

This resulted in a unique system of federalism in the country where each state that forms the federation has the right to secede from the union. This right is enshrined in article 39 of the 1994 constitution and has been and remains to be a bone of contention between the government and pan-Ethiopian opposition parties (Ibid). Creating a federation along ethnic lines and the prominent position of ethnicity in state politics has a number of implications for conflict generation and management. Before discussing these points; however, a theoretical overview on origin and the types of federalism comes in order.

\section{Federalism: A Theoretical Overview}

Federalism is essentially a system of government in which there is a share of power between national and regional political units (Ariyo, 2003). This sharing of power between the different tiers of government however is complex as it introduces a range of issues that has to do with diversity, unity, interdependence as well as cooperation and conflicts (Tamuno, 1998).

In terms of types of federal arrangements, Ariyo notes that 'federalism is about nature and form of association among interacting states' and suggests two types of federalism based on the nature of how the system develops. These are the dual federalism and the cooperative federalism. In the former case, there are independent levels of government with distinct responsibilities as stated by law. In the latter, there is a higher degree of partnership between the different tiers of government with the focus on delivering effective services through cooperation. It could be said that the dual form of federalism seems to take the arrangement as an end by itself whereas the cooperative one implies the use of federalism as a means to an end (Ariyo, 2003:1). Thus, the adaptability of federalism according to the 
context and specific nature of a political society is not well visible in such a category.

The aims of setting-up a federal state are crucially related to the circumstance of the individual countries. As such the prospect of creating a larger state and benefit from better access to economic and military resources is one of the advantages of federalism. Moreover, in a poly-ethnic state like Ethiopia, federalism is argued to help promote democracy as it prevents tyranny of the majority. It could also help to limit the power of the government by balancing it in the institutional division of powers of branches of government and the territorial division of power between the center and the states (Ephrem, 2010).

Another useful classification of federalism that reflects the concern for context specific characters is the distinction made between the two main ways in which federal systems come into being. These, according to Keller, are the 'coming together' and 'holding together' types of federalism (Keller, 2002). There is also a third variant that Stepan termed as 'putting together' federalism which reflects the experience of Ethiopia (Stepan, 2001).

\section{Coming Together Federalism}

Coming-together federations emerge when two or more existing sovereign nations consent to establish a federal system for governmental efficiency, economic development, and security purposes. Such federations can advance economic growth by removing barriers for trade and by promoting peace. The crucial feature of 'coming-together' federation is that the union is formed on voluntary basis (Keller, 2002 and Ephrem, 2010).

\section{Holding Together Federalism}

This type of federation involves a division of a polity into different sub-units with each having its own sovereignty with respect to some policies. It stands opposite to the coming together federalism in which sovereign states come together to create a common central government by surrendering a portion of their sovereignty. It is often considered as a political approach employed to save a disintegrating unitary state and to manage ethnic divisions (Keller, 2002).

\section{'Putting Together' Federalism}

This refers to a union that comes together through coercion or deceitful inclusion of various units by organized elite. The former USSR is a typical example of such nominal federation with a strong degree of centralization (Ephrem, 2010). Ethiopia began to experiment with holding together federalism in 1991 with the various 
ethnic groups having the right of self-governance. However, as Keller argues the country changed its course to putting together type of federalism as the political sphere becomes ever more centralized by the TPLF-led federal government (Keller, 2002).

Keller asserts that Ethiopia's ethnic federalism has not featured a democratic federalism that devolves authority and decision making to lower levels of government. He further argues that the system exhibits a growing tendency of centralization in which politics and development is controlled by the centre (Keller, 2002).

Ethiopia's decision to implement federalism was negotiated between the regional elites. However, the relative strength of the regional elites was weaker as compared to the TPLF or Tigran elites that led the armed struggle against the Derg indicating that the whole process was flawed by power imbalance even at the inception (Tesfaye, 2002). Some argue that the decision to adopt a federal structure was made in response to the ethnic nationalism movements that threatened the unity of the country (Frank, 2009). Without ruling out external pressure to decentralize, this internal factor seems evident in the number of ethnicbased secessionist political organizations that participated in the conference summoned by TPLF/ EPRDF in July 1991 to form a Transitional Government. The national conference named 'Democratic and peaceful transitional Conference' involved representatives of 31 political movements (most of them ethnic-based liberation fronts such as the Oromo Liberation Front (OLF)). The conference barred certain political groupings that follow a different ideology than EPRDF such as Ethiopian people's Revolutionary Front (EPRP), all Ethiopian Socialist Movement (MESON) and the Coalition of Democratic Ethiopian Forces (CODEF). All these organizations have multi-ethnic political programs based on civic nationality or they were pan-Ethiopian movements (Tesfaye, 2002).

The Ethiopian federal system is also described as asymmetric both in terms of territorial organization and balance of power. The system created asymmetries between states since the federation now composes populous and big states like Oromia with that of Harar which is a city with the ethnic composition of the Hararies accounting only $7 \%$ of the population (Asnake, 2009).

Self-government, decentralization and representation in the central (federal) government are important elements of federalism and thus constitutionally all the regional states in Ethiopia have their own judiciary, legislative power and are represented in the federal government and conduct their affairs (Minasse, 1996). Thus, on paper the country is a federation, however, according to Aalen, this contradicts with the reality that the ruling party follows a very centralized control 
over all affairs in the country through its affiliates in the regions. Thus, a real federation is a matter of controversy due to this tighter grip by the ruling political elites (Aalen, 2002).

\section{Ethnicity and Ethnic Cconflict Theory of Ethnicity}

There are two major schools of thought on ethnicity- primordialism and constructivism. Primordialism focuses on self-determination and takes emotional and primordial attachment to fixed social characteristics, such as blood ties, race, language, region, and custom. Such an attachment necessarily looks for political sovereignty as a basic means to protect and develop the valued characteristics. According to primordialists, the ideal means to resolve ethnic conflicts is therefore to allow for the right to self-determination up to secession (Cordell and Wolff, 2010). Such assertion seems to corroborate with the use of ethnicity in political mobilization in the current federal system in Ethiopia.

The constructivists take ethnicity as an adaptive and flexible phenomenon and assert that it is primarily an entity that people use opportunistically to promote their interests. They also take ethnic identities as amenable to strategic decisions including discarding one's ethnic identity when alternative affiliations promise a better return (Ibid). Ethnic identities are therefore seen as fluid and individuals are considered to be capable of manipulating their identities or of others when either they feel a sharp need of cultural recognition or seek to pursue some political agenda (Ibid).

Ethnic conflict may be defined as a conflict between two or more ethnic groups over resources, identity, borders or against political oppression (Reatile, 2004). According to Michael an 'ethnic community' is a named human population with a myth of common ancestry, shared memories, and cultural elements, which has a link with historical territory or homeland, and a measure of solidarity (Michael, 1997: 210). According to Brown, there are six criteria that must be met for considering a group as an ethnic community. These criteria include having a name for one's own community, believing in a common ancestry, mutual historical experiences, a shared culture, territory, and collective self-awareness (Brown, 1997).

Generally, the term conflict refers to a situation in which two or more actors pursue incompatible, yet justified goals (according to their points of view). Thus, ethnic conflicts are one of such conflicts in which the goal of at least one actor in the conflict is defined in ethnic terms with the main cause of confrontation being ethnic distinctions and dissatisfactions (Wolff, 2006). 
According to Rothman, 'ethnicity has never been absent from politics, and it only achieved visible expressions in post-colonial Africa (Rothman, 1997: 43).' It is common for disputants to totally miss each other when they speak about their respective needs and aspirations. The consequences of such misunderstandings always show us the erosion of mutual trust and the waning of tolerance. Identityconflicts are often hard to identify since they usually get confused with disputes over tangible resources. More importantly, though theoretical distinctions between identity and interest conflicts may be valid, their differences are not so precise and clear-cut in practice. However, it is fair to say that while all identity conflicts contain interest conflicts; not all interest conflicts contain identity conflicts.

Kaufman uses the security dilemma as explanatory variable in ethnic relations and conflict. He considers ethnic groups not as unified entities but as arenas of interacting elites and masses that produce the dynamics of security dilemma leading to conflict. He also stresses on the role of elites vis-à-vis masses in shaping ethnic identities by asserting that ethnicity needs to be viewed through the constructionist lens (Kaufman, 1996). One of the pre-conditions for ethnic conflict according to Kaufman, is the creation of opportunities for mobilization which can be manifested in the political space such as political freedom, territorial base in a neighbouring country as well as state failure (Kaufman, 2001 as cited in Cordell and Wolff, 2010).

All these adequately reflect the history of ethnic conflicts in Ethiopia and the use of ethnic identities in politics mainly by The Eritrean People Liberation Front (EPLF) and the TPLF which have a long history of armed struggle in Ethiopia. Thus, the country's advent into ethnically based federalism can be taken as an example of the instrumental use of ethnicity for mobilizing people to gain political power by elites (Minasse, 1996). The system of ethnic federalism according to Messay seems to be a result of a deliberate policy imposed by the ruling elites to promote ethnicization in the country at the expense of national integration. Such moves contrast with how federalism is used to reduce ethnic tensions and maintain unity in countries such as India and Nigeria (Minasse, 1996; Messay 2009).

\section{Research Approach}

This paper followed two methodological approaches to the analysis of ethnic conflict and its relationship with ethnic federalism in Ethiopia. First, it used document review of several cases of ethnic conflicts by organizing these cases into similar and dominant themes. The themes provide an overview of federalism in Ethiopia along with its origins and its main features, and discuss the concept of ethnicity and looks into the theories of ethnic conflict laying the ground for further 
discussion. In addition, the paper uses the Armed Conflict Location and Event Data Project (ACLED) to analyse the trend in ethnic conflict so as to provide more rigorous empirical evidence on the subject by implementing linear regression model, which is presented in Appendix A. The two approaches were used concurrently to strengthen the validity of the findings and conclusions. However, the paper does not attribute that ethnic conflicts in Ethiopia are solely due to ethnic-based federal arrangement. It rather discusses the trends in ethnic conflicts by focusing only on those that can be associated with ethnic boundary disputes attributable to elite mobilization and political agitation of communities.

\section{Ethnic Conflict in Ethiopia: Types and Trends}

The debate on the effects of the ethnic federal structure on conflict in Ethiopia has been normative and divergent. The supporters of the current federal system argue that the system has ushered the country into a new era of democracy by addressing the legacy of ethnic inequality. They assert that this arrangement could reduce conflict and tensions by promoting accommodation, self-rule, harmony and coexistence among ethnic groups in multi-ethnic countries and help to reduce secessionist movements and national disintegration in countries like India and Switzerland (Andreas, 2004 and Kymlicka, 2006).

Critics, however, argue that the use of ethnicity as the main organizing device of the federation have compartmentalized the political space by encouraging a primordial notion of identity which in turn promotes secessionism and puts the nation in a quagmire of endless conflicts. Such critics cite the cases of dissolved ethno-federal arrangements such as that of the USSR, Yugoslavia and Czechoslovakia.

In this regard, empirical studies show that ever since the introduction of the ethnic-based federal structure in Ethiopia, there have been an upsurge of ethnic conflicts and the sharpening of boundaries among the different ethnic groups (Aalen, 2002) and ethnicity has become an instrument of political mobilization and perpetuating violence, dissension and a growing sense of separatism in Ethiopia (Muhabie, 2015).

Essentially, the issue that ethnicity being given primacy over other notions of state organization, political representation as well as resource entitlement led to the constitution of institutions that legalize and drew boundaries among the different ethnic groups. Thus, defining the identities of many communities became a practical challenge and often led to the eruption of conflicts in many regional states (Ibid). 
Case 1: Conflict between Oromo and Ethiopian Somali communities

Members of the elders' council in Ethiopia Somali regional state remembered the long years of inter-tribal conflict that prevailed in the region which obstructed development interventions. With recognition and strong support obtained from the regional government, the elders' council has contributed much to the stability of the region. The elders' council has resolved such conflicts and studied the nature of cross border and inter-ethnic conflicts in the region. During the 8th session of a regional level consultative conference held in May 2017 in Jigjiga city, the issue of inter-ethnic conflict particularly conflict between people of the Ethiopian Somali and Oromia regional states were one of the major discussion agenda along with drought. Participants informed the regional government how conflict took away lives of people and resulted in IDPs in the region. According to them, competition for land resources particularly scarce water and grazing has always been prominently inherent sources of disputes between the two communities. Both pastoralists and farmers needed more land to graze their livestock and produce crops. However, these conflicts now have a political motive along the border areas of both communities. According to key informants of this study, both communities until recently have been in a state of war particularly in South and North west side of the Ethiopian Somali regional state along the border extending from Moyale to Muli Woreda near Meiso. The ever increasing ethnic conflicts and tensions between the two groups resulted in increased population of IDPs. IOM report supports the elders' narrative on growing population of IDPs. According to the report, Liben, Erer and Fafan zone alone hosted over 17,000 and about 13,000 IDPs of conflict settled in Siti zone since 2014 ( IOM, 2017). Referring to the Ethiopian government and its humanitarian partners, IDMC also indicated around 67,800 people to have displaced due to communal conflict associated to drought in Oromia and Ethiopian Somali regional State between 2015 and 2016 (IDMC, 2016). The conflict between the two has recurred again in the border areas particularly around Moyale and its environs costing lives of civilians, people in military uniform and is still ongoing prompting the national defense force to intervene with the order of the ex-Prime Minister. The conflict re-occurred with a political motive on the $4^{\text {th }}$ of August 2018 resulting in the death of people and huge destruction of businesses and houses in Jigjiga, Gode, Kebridahar and Degahabur towns. A youth group known as Heego was blamed to have coordinated the attacks on non-Somali ethnic groups and political figures of the then Ethiopian Somali People Democratic Party (now Somali People Democratic Party including the former president of the region, Abdi Mohammed Oumer) who are under custody of police. 
Ethnic conflicts (Case 1) are further aggravated by drought related and natural factors shrining the negotiation space that otherwise prevailed in the past in the use of the commons. That is part of the reason that many scholars tend to be sceptical about the use of ethnicity as an organizing principle in Ethiopian federalism along with the right to secession provided in the constitution. For instance, Lyons argues that the ethnicization of politics prompts ethnic conflict and encourages political activism on ethnic issues and fragment national politics (Lyons, 1996). Thus, the system has increased localized conflicts which seem to work to the advantage of the ruling regime that wants to keep the centre free of strong political opposition. Following the coming of Prime Minister Abiy Ahmed to the chairpersonship of EPRDF, however, the nationalist and reconciliation agenda has dominated the political discussion as reflected in many of his speeches. This is also evident in his successful effort in restoring normal diplomatic relationships that put to rest the twenty years old no war no peace status quo between Eritrea and Ethiopia.

\section{Case 2: Conflict between Afar and Issa clan of the Somali communities}

External factors exacerbate ethnic conflicts and animosity (Soeters, 2005 and Suhrke et al., 1977). Similar interventions in the past are to blame for continued conflict between the Afar and the Issa clan of the Somali community. Such a conflict is further aggravated by competition for scarce resources, territorial expansion and cultural ethos (Getachew, 1997 and Thesiger, 1935). For most of the period since 1997, there was tense conflict up until 2015 when a peace deal was brokered by the federal government of Ethiopia that gave back the three Woredas (Gedamayitu, Undufo and Adayitu) to Afar regional state. Informants of the research disclosed that despite the political victory of re-claiming their land on the Afar side, absolute stability is far from being reached. Conflicts between the two communities seem to continue as the Issa demand for self-rule and special Woreda status intensifies.

Ethnicity being the major organizing principle of the federal system has implications for increasing localized conflicts which are indicated to have become consistent characteristics in ethnic relations in Ethiopia. In this regard, Asnake outlines the following four major trends of conflict in the country (Asnake, 2009: 99-104).

\section{Federal Restructuring and Identity Conflicts}

The central position of ethnicity in the Ethiopian federal system means that groups wanted to have a recognition as a 'nation, nationality or people' and representation 
in politics. This was fairly easy for the relatively larger ethnic groups. However, defining the ethnic identity of many minority ethnic groups has emerged as one of the areas of local/regional conflicts. Moreover, institutionalization of ethnicity based on primordial features of identity added fuel to the conflict as groups considered part of another ethnic group have now resorted into a struggle for recognition of separate ethnic identities as this could lead to representation at regional and federal tiers of government. An example of such identity conflict is the one between the Gurage and the Silte groups in the south region that eventually resolved through referendum.

Thus, it could be argued that such trends of Ethnic federalism based on primordial thinking of identity could contribute to the undermining of communal bonds and increases tensions between clans of the same ethnic or linguistic groups. This can further erode the age-old networks and trust among people that form their social capital which is imperative for economic growth.

\section{Intra-federal Boundary Conflicts}

The restructuring of the state into federal system required the drawing of boundaries which is at least in theory congruent with ethnicity. However, this process was not smooth as there is no clear overlap between ethnicity and territories due to a great degree of mobility of ethnic groups in all directions. As a result, this generated a number of conflicts among ethnic groups that live in the same or neighbouring regions. Examples here include the conflict between the Gedeo and the Guji in southern Ethiopia that used to live in the former Sidamo province before 1992. In line with the principles of ethnic regionalization, the Guji who belong to the Oromo ethnic group became part of the Oromia region, while the Gedeo became part of the South region. In a very recent scenario in 2018 over 800,000 people were displaced due to the conflict resulting in the largest conflict of IDPs in the country.

\section{Intra-regional Conflicts in Multiethnic Regions}

Ethnic based federalism created asymmetrical federal structure in which larger ethnic groups (such as the Oromo and Amhara) were given their own ethnic regions and the smaller (all groups in South, Gambella and Bengeshangul regions) were put together to establish multi-ethnic regions. In all these regions, interethnic conflicts become rampant triggered by disputes over the sharing of political power and resources. An example here is the ongoing conflict between the Anywak and the Nuer in Gambella region. 
Case 3: Conflict between Afar and Amhara communities

The establishment of regions along ethnic lines has, however, aggravated the territorial nature of the conflict resulting in the disruption of negotiated access to resources in each other's jurisdiction. Recently, the seemingly sporadic nonresource based conflict between the two ethnic groups is gradually getting tense. According to key informants, demographic changes particularly settlement expansion and the controversy over regional boundaries are the causes of such conflict. In May 2017, over 8 people lost their lives of which security officials are amongst them. Following the Ramadan holiday, the conflict broke out again claiming lives of others from both sides and came to a halt by the intervention of the federal police forces. This is an indication of how serious the conflicts have become. Most of the conflicts between the two ethnic groups have changed their discourse from being predominantly seasonal resource type into being territorial political disputes recently. The majority of such conflict encounters occur in the resource scarce and under developed border areas of the two regions further complicating the relative development and security gains of the areas.

\section{Conflicts between Titular and Non-titular Groups}

The lack of overlap between personal and territorial ethnicity due to the settlement of individuals and communities beyond their ethnic and administrative boundaries, has made it impossible to maintain an ethnically homogenous states. As a result, a significant portion of Ethiopians live out of their supposed ethnic homelands and this has affected the relationships between titular and non-titular communities. This problem has been worsened by the fundamentally primordialist notion of ethnicity that conquers in the political discourse of the country. Asnake stated the gaps federalism and territorial autonomy have while addressing multiethnic governance and the representation of non-titular groups in local and regional government with the exception of the informal arrangement in Dire Dawa city (Asnake, 2014).

The federal structure changed the relationships between the titular and nontitular groups. While the titular groups actively pursued their new autonomy to affirm their economic and political power, the non-titular groups felt a growing sense of insecurity and discrimination as they were excluded from politics and become minorities. Thus, many conflicts erupted in the relationships between the two groups in many parts of the country such as Harari.

Thus, it seems that the ethnic federalism in Ethiopia has not reduced conflict as its proponents argue. In fact, it has contributed to increasing tendencies of conflicts that are more local and ethnic in their nature. This fact is noted by the 
International Crisis Group's report in 2009. “The EPRDF's ethnic federalism has not dampened conflict, but rather increased competition among groups that vie over land and natural resources, as well as administrative boundaries and government budgets (ICG, 2009: 3)."

From the onset the federal system has created regional states that are not ethnically homogenous except for the Afar and the Somali regions; there are significant proportions of other ethnic groups that live in all regions as minorities. The system was also imposed from the top without much debate and gave more space for politically ambitious elites to create their own ethnic political organizations that instigated conflicts and dislocation for such ethnic groups designated as minorities live outside of their ethnic homelands. This could be attested by the frequency of overall conflicts disaggregated by type of actors in Ethiopia from 1997 to 2016 that indicates a sharp increase in major ethnic conflicts (See Figure 1). The figure shows an increasing trend in the frequency of major ethnic conflicts that occurred in Ethiopia between 1997 and $2016\left(R^{2}=0.30, p=0.01\right)$ this up-ward trend in ethnic conflicts also corroborates with previous findings from Abbink's study of ethnicity and conflict generation in the context of 'ethnoregional federalism' from 1991 to 2005 (Abbink, 2006). The first period roughly corresponds to the institution of federal constitution in 1994 and the second with climatic shocks and political instability at the centre following internal party conflicts and the war with Eritrea. These conditions are likely to have increased ethnic conflicts that are prompted by boarder and resource sharing. 


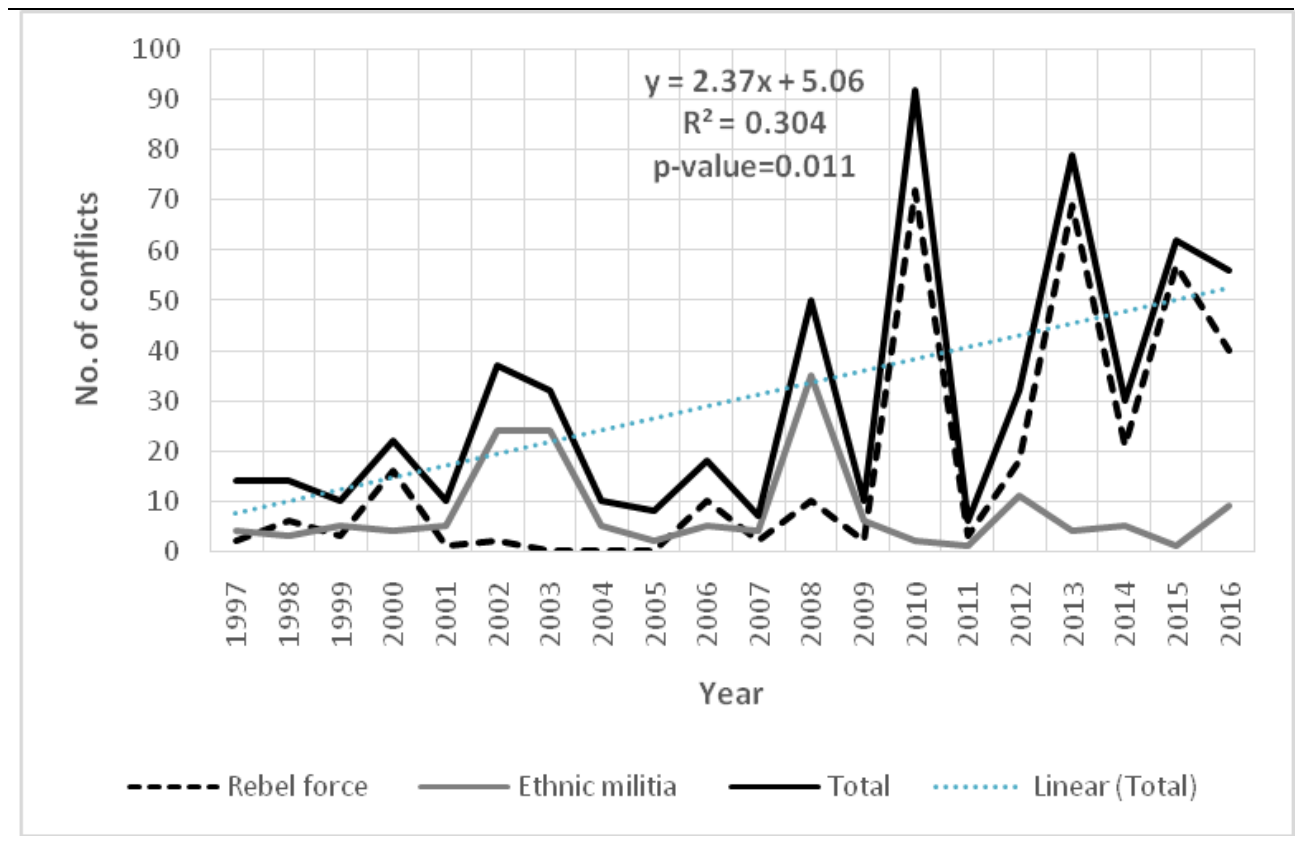

Figure 1: The frequency of major conflicts in Ethiopia by types of actors 1997$2016^{1}$ (Source): Authors' computations from Armed Conflict Location and Event Data Project (ACLED) Version 5.

\section{${ }^{1}$ Notes}

The ACLED project codes reported information on the exact location, date, and other characteristics of politically violent events in unstable and warring states. ACLED focuses on tracking a range of violent and non-violent actions by political agents, including governments, rebels, militias, communal groups, political parties, rioters, protesters and civilians. Data contain specific information on the date, location, group names, interaction type, event type, reported fatalities and contextual notes. ACLED Version 5 data cover all countries on the African continent from 1997-2014. Weekly, real-time data is available for African states at acleddata.com; monthly data for South and South East Asian states is available monthly as of 2015. Earlier versions of the ACLED dataset cover political violence in African states in earlier years (Versions 4 through 2). In Ethiopia's case, rebel forces are mainly organized and mobilized on the basis of ethnicity. Thus, for analytical purpose, this paper merged the interaction code for rebel force with ethnic militia and treats the two as indicators of ethnic conflict. 
According to Aalen, the South region can serve as a show case for the dramatic increase in a number of conflicts labelled as ethnic since it hosts 56 ethnic groups and several sub-ethnic and clan divisions (Aalen, 2002). Thus, with the introduction of ethnic federalism, the various ethnic groups started to compete for administrative boundaries led by entrepreneurial elites that wanted to redefine ethnic identities in order to gain control of political power. This phenomenon increased the number of conflicts in the region. The prominent ones include the conflicts between the Gurage and the Silte, the Sidama and Wolayeta, and the Guji and the Gedio. In 2018, the killings by xenophobic groups that demanded the ethnic Wolayeta to leave Hawassa city and the conflict between Guji and Gedio both in South Nations, Nationalities and People's Region are examples worth mentioning.

Similarly, there have also been administrative units that triggered seemingly endless demands for political boundaries which resulted in more ethnic strife in most regional states like Beneshangul and Gambella (Asnake, 2009). Thus, previous conflicts that were along the lines of resources and livelihoods have now begun to be defined in terms of ethnic lines. This makes conflict mitigation inherently difficult as it creates the mobilization of large groups (Aalen, 2002). As noted by Roeder, ethno federal and autonomy arrangements are likely to 'establish incentives for politicians to engage in confrontations over decisions, rights and link their confrontations to competing nation-state projects that can escalate to sovereignty claims' (Roeder, 2009: 211).

There are also clear cases of intra-ethnic conflicts which would bring a revival of clan identities as an important way of taking up local political positions. This revival of clanship according to Aalen has resulted in active ethnic group markers such as heightened inequalities between clans; discrimination against certain groups and women as well as the practice of harmful traditions like abduction and female circumcisions (Aalen, 2002).

There has been a revival of conflicts that are often instigated by political elites that use identity politics as a means to capture political positions. This in some cases led to the institutionalization of new language. A case in point is the conflict among Wolaitta, Gamo, and Dawro over 'WoGaGoDa' between 1999 and 2000 as discussed by Abbink. Moreover, conflicts over identities and territories increased as ethnic groups continuously vied to gain separate administrative status in the form of special districts within regional states. As a result, in the two decades between 1997 and 2016 close to 33 major ethnic-based conflicts erupted in the country owing mainly to boundary disputes and demarcations fuelled by political elites that compete for regional autonomy and power (see ACLED Fig 1). 
Moreover, as Roeder suggests, the existence of ethnic homelands can create opportunities for 'ethnic entrepreneurs' to press for their claims successfully against a common-state government helping to protract ethnic conflicts. This has been clearly demonstrated by the surge in the number of ethnic conflicts in Ethiopia in recent years, which is likely to have an increasing trend (see Figure A and B Appendix B).

\section{Conclusion}

Federalism has been and is still used as a remedy for the problem of managing ethnically diverse countries. However, whether federalism delivers its promises of recognition and respect for the range of political, cultural and ethnic rights and therefore reduction in ethnic tensions and conflicts largely varies depending on the context and the political culture. Thus, it seems that factors like the nature of the federation, its evolvement and the role of political elites and the basic principles used to organize the system matters a lot.

The available evidences seem to suggest that ethnic federalism in Ethiopia is not helping reduce ethnic tensions and conflicts. In fact, conflict is escalating due to the ethnic heterogeneity of the regional states and the resource plus boundary sharing between different groups. Conflicts are increasing and becoming decentralized which seems to defy the argument that ethnic federalism can be a typical strategy for avoiding conflict in multi-ethnic societies. In fact, the Ethiopian case seems to highlight the roles of political elites and their capacity to manipulate ethnic identities at the expense of societal stability. Thus, there is a need to promote ties between the various ethnic groups based on civic notions of nationality and using commonly shared values in view of the past achievements and future economic development. In this regard, the sole criterion of using ethnicity to organize the federation should be overhauled to accommodate for geographical and economic considerations as well as creating unity in diversity, recognizing the intermix of people and the cross-ethnic institutions that existed for millennia.

\section{Acknowledgement}

The authors would like to thank Prof. Mitja Zagar from the University of Ljubljana for his valuable comments to an earlier draft of this paper. 


\section{References}

Aalen, Lovise. (2002). Ethnic Federalism in a Dominant Party State: The Ethiopian Experience 1991-2000. Chr. Michelsen Institute.

Abbink, Jon. (2011). "Ethnic-Based Federalism and Ethnicity in Ethiopia: Reassessing the Experiment after 20 Years." Journal of Eastern African Studies, 5(4): 596-618.

Abbink, Jon. (2006a). Ethnicity and Conflict Generation in Ethiopia: Some Problems and Prospects of Ethno-Regional Federalism, Journal of Contemporary African Studies, 24 (3): 389-406.

Andreas Eshete. (2004). Ethnic Federalism: "New Frontiers in Ethiopian Politics." Proceedings of the 1st National Conference on Federalism, Conflict and Peace Building, May 5-7 2003. Addis Ababa, Ministry of Federal Affairs, United Printers, pp. 142-172.

Ariyo, A. (2003). Fiscal Policy and Growth in Africa: Fiscal Federalism, Decentralization and the Incidence of Taxation. Economic Commission for Africa, Ad-Hoc Expert Group Meeting 7-9 October 2003, UNECA, Addis Ababa.

Assefa Fiseha. (2012). "Ethiopia's Experiment in Accommodating Diversity: 20 Years' Balance Sheet." Regional \& Federal Studies 22(4): 435-73. doi:10.1080/13597566.2012.709502.

Asnake Kefale. (2014). "Ethnic Decentralization and the Challenges of Inclusive Governance in Multi-ethnic Cities: The Case of Dire Dawa, Ethiopia." Regional \& Federal Studies, 24(5): 589-605.

doi:10.1080/13597566.2014.971772.

Asnake Kefale. (2010). "Federal Restructuring in Ethiopia: Renegotiating Identity and Borders along the Oromo-Somali Ethnic Frontiers." Development and Change, 41(4): 615-35.

Asnake Kefale. (2009). Federalism and Ethnic Conflict in Ethiopia: A Comparative Study of the Somali and Benishangul-Gumuz Regions. (Doctoral thesis). Department of Political Science, Faculty of Social and Behavioral Sciences, Leiden University (last checked 12 May 2008).

https://openaccess.leidenuniv.nl/handle/1887/13839

Bahru Zewde. (1991). A History of Modern Ethiopia, 1855-1974. London: James Currey.

Burgess, Michael. (2006). Comparative Federalism: Theory and practice. New York: Routledge. 
Cheung, Wing H., Gabriel B. Senay, and Ashbindu Singh. (2008). "Trends and spatial distribution of annual and seasonal rainfall in Ethiopia." International Journal of Climatology, 28(13): 1723-1734.

Cordell, Karl and Wolff, Stefan. (2010). Ethnic conflict: causes- consequencesresponses. Polity Press.

Erk, J. and Anderson, L. (2009). "The Paradox of Federalism: Does Self-Rule Accommodate or Exacerbate Ethnic Divisions?" Regional and Federal Studies, 19(2): 191-202. doi: 10.1080/13597560902753388.

Ephrem Madebo. (2010). Ethnic Federalism and One Party Rule in Ethiopia, URL (Last checked 26 March 2012)

http://ecadforum.com/articles/2010/03/15/ethnic-federalism-and-one-partyrule-in-ethiopia/.

Foreign Policy. (2011). The Failed States Index 2011. URL (last checked 12 November 2012)

http://www.foreignpolicy.com/articles/2011/06/17/2011_failed_states_index_ interactive_mapand_rankings

Frank, Marijke. (2009). "Effects of Ethnic Federalism in Ethiopia. Holding Together or Splitting Apart?" Ethnicity, Diversity and Democracy, EDG Project Guadalajara: Summer Institute.

Frei, Christoph. (2014). Analysis of Climate and Weather Data. Zurich: Institute for Atmospheric and Climate Science. 1-37. Retrieved from https://www.iac.ethz.ch/edu/courses.

Getachew Kassa Negussie. (1997). 'A Case Study of the Afar in the Middle Awash, Northeastern Ethiopia', Paper Presented to the 13th International Conference of Ethiopian Studies. Kyoto.

Habtu Alem. (2005). "Multiethnic Federalism in Ethiopia: A Study of the Secession Clause in the Constitution." Publius: 313-35.

Henze, B.P. (2000). Layers of Time: a history of Ethiopia. C Hurst \& Co Publishers.

International Crises Group (ICG). 2009. Ethiopia: Ethnic Federalism and Its Discontents (Crisis Group Africa Report $\mathrm{N}^{\circ} 153$ ). Nairobi/Brussels. Retrieved from: https://www.crisisgroup.org/africa/horn-africa/ethiopia/ethiopia-ethnicfederalism-and-its-discontents

Internal Displacement Monitoring Centre (IDMC). (2016). Global Report on Internal Displacement. Geneva, Switzerland

International Organization for Migration (IOM). (2017). Displacement Tracking Matrix (DTM) Somali Region, Ethiopia. Round III: January to Feb 2017. 
Retrieved from: https://reliefweb.int/report/ethiopia/ethiopia-displacementtracking-matrix-dtm-somali-region-round-13-septemberoctober

Jain, Sharad K., and Vijay Kumar. 2012. "Trend analysis of rainfall and temperature data for India." Current Science (Bangalore), 102(1): 37-49.

Karmeshu, Neha (2012). Trend Detection in Annual Temperature \& Precipitation using the Mann Kendall Test - A Case Study to Assess Climate Change on Select States in the Northeastern United States (Master of Environmental Studies Capstone Projects, 47). University of Pennsylvania: Department of Earth and Environmental Science.

Kaufman, Stuart. (2001). Modern hatreds: The symbolic politics of ethnic war. Cornell University Press.

Kaufman, Stuart. (1996). An 'international' theory of interethnic war. Review of International Studies, 22(2): 149-171.

Keller, Edmond J. (2002). "Ethnic Federalism, Fiscal Reform, Development and Democracy in Ethiopia." African Journal of Political Science, 7(1): 21-50.

Kymlicka, W. (2006). Emerging Western Models of Multinational Federalism: Are They Relevant for Africa?' In T. David (ed.) Ethnic Federalism: The Ethiopian Experience in Comparative Perspective. Oxford: James Currey, Athens: Ohio University Press and Addis Ababa: Addis Ababa University Press.

Lyons, T. (1996). Closing the Transition: The May 1995 Elections in Ethiopia. The Journal of Modern African Studies, 34(1).

Madsen Henrik, Deborah Lawrence, Michel Lang, Marta Martinkova, and T. R. Kjeldsen. (2014). "Review of trend analysis and climate change projections of extreme precipitation and floods in Europe." Journal of Hydrology, 519 (2014): 3634-3650.

Markakis, J. (1974). Ethiopia: Anatomy of a Traditional Polity. Addis Ababa: Oxford University Press.

McGarry, John. (2005). "Can Federalism Help to Manage Ethnic and National Diversity?" Federations. 5, no. A-1: 15.

Messay Kebede. (2011). Ideology and Elite Conflicts: An Autopsy of the Ethiopian Revolution. Lanham, Maryland: Lexington Books.

Messay Kebede. (2009). In search of peace: Ethiopia's ethnic conflicts and resolution (Last checked 8 May 2012) http://www.abugidainfo.com/index.php/9665/

Michael, E.B. (1997). Causes and Implication of Ethnic conflict in Monte serrate. In Guiberau and R. John, (eds.). The Ethnicity Reader: nationalism, multiculturalism and migration. Polity press, UK. 
Zerihun Berhane and Samuel Tefera

Minasse Haile. (1996). The New Ethiopian Constitution: Its impact upon Unity, Human Rights and Development. Suffolk Transnational Law Review, 20(1): $1-85$.

Muhabie M. (2015). Ethnic Federalism: A Means for Managing or a Triggering Factor for Ethnic Conflicts in Ethiopia. Social Sciences, 4(4): 94-105. doi: 10.11648/j.ss.20150404.15

Reatile, V.S. (2004). Ethnic Conflict in the Horn of Africa (Occasional paper No. 19). Electoral Institute of South Africa (EISA).

Roeder, Philip G. (2009). "Ethnofederalism and the Mismanagement of Conflicting Nationalisms." Regional \& Federal Studies, 19(2): 203-19. doi:10.1080/13597560902753420.

Rothchild, Donald. (1966). "The Limits of Federalism: And Examination of Political Institutional Transfer in Africa." The Journal of Modern African Studies, 49(3): 275-93.

Rothman, Jay. (1997). Resolving Identity-Based conflict in Nations, Organizations and Communities. San Francisco: Jossey-Bass Inc, publishers.

Soeters, J. L. (2005). Ethnic Conflict and Terrorism: The Origins and Dynamics of Civil Wars. London: Routledge

Stepan, Alfred. (2001). Arguing Comparative Politics. New York: Oxford University Press.

Suhrke, A., \& Noble, L. G. (1977). Ethnic conflict in international relations. New York: Praeger Publishers.

Tamuno, T. 1998. Nigerian Federalism in Historical Perspective. In K. Amuwo, A. Agbaje, R.Suberu \& G. Herault, (Eds.). Federalism and Political Restructuring in Nigeria. Spectrum, Ibadan.

Tesfaye Aaron. 2002. Political Power and Ethnic Federalism: the struggle for democracy in Ethiopia. University Press of America. Lanham.

Thesiger, Wilfred. (1935). 'The Awash River and the Aussa Sultanate,' The Geographical Journal, 85(1).

The Fund For Peace. (2018). Fragile States Index 2018. Washington, D.C Retrieved from: www.fundforpeace.org..

Van der Beken, C. 2010. "Minority Protection in Ethiopia-Unravelling and Improving Ethnic Federalism." Recht in Afrika , 13( 2): 1-30.

Watts, Ronald. (1994). "Contemporary Views on Federalism." Evaluating Federal Systems, 1-29.

Watts, Ronald L. (2001). The International Evolution of Federal Systems in the Twentieth Century. Queen's University-Kingston, Ontario, Canads: Institute of Intergovernmental Relations. 
EJOSSAH Vol. XIV, No.1

June 2018

Wolff Stefan. (2006). Ethnic Conflict: A Global Perspective. Oxford: University Press.

Wooldridge, Jeffrey M. (2008). Introductory Econometrics: A Modern Approach. Cengage Learning.

Zhang, Xuebin, Lucie A. Vincent, W. D. Hogg, and Ain Niitsoo. (2000). "Temperature and Precipitation Trends in Canada During the 20th Century." Atmosphere-Ocean, 38(3): 395-429. 


\begin{abstract}
Appendix A: Linear Regression Model
Trend refers to the rate at which a certain event such as conflict changes over a time period and it is often determined by the relationship between this variable and time (Zerihun and Prowse, 2013). The magnitude of trend in a time series can be determined by parametric tests (using regression analysis) or non-parametric tests (e.g. Mann-Kendall trend test). In this study we first implemented linear regression model to test the existence of trend on conflict data.

The linear regression analysis is used with time as the independent variable and the number or frequency of ethnic-based conflicts as the dependent variable. This method is extensively used in other fields of investigation such as climate change studies (See Cheung, Senay and Singh, 2008; Karmeshu, 2012 ; Jain and Kumar, 2012). The linear regression model is given by:
\end{abstract}

$$
y=\alpha+\boldsymbol{\beta} \boldsymbol{X}+\boldsymbol{\varepsilon}
$$

where, $y$ is number of ethnic-based conflicts (the dependent variable);

$\alpha$ is the intercept;

$\boldsymbol{\beta}$ is the coefficient of the explanatory variable (the slope)

$\boldsymbol{X}$ is the independent variable (time) and;

$\varepsilon$ is the stochastic term (the residual)

The linear trend value is represented by the slope of the simple least-square regression line. The linear regression model makes strong assumptions about the distribution of the dependent variable ( $y$ ) over time. These assumptions mainly apply to the residuals being normally distributed, independent (with no serial correlation), and identically distributed (with constant variance) (Frei, 2014).

In most cases, time-series data are assumed to consist of a long-term trend component and a white noise residual component (i.e. with no serial correlation) (Madsen et al., 2014; Frei, 2014). In practice, due to the multi-year existence of natural climate variability (Zhang et al., 2000), errors from adjacent time periods may be correlated across time. In this context, assuming white noise residuals may result in overestimating the significance of the trend (Wooldridge, 2008).

Therefore, after checking the model for the critical assumptions, the t-test (parametric test) is used to assess whether the slope's coefficient of the fitted linear regression is significantly different from zero, indicating the presence of a linear 128 
EJOSSAH Vol. XIV, No.1

June 2018

trend. The null hypothesis for the test is that $\boldsymbol{\beta}=0$ (data not linearly dependent on time) and the alternative hypothesis is $\boldsymbol{\beta} \neq 0$.

The test statistic (linear regression T-Test) is given by:

$$
t=\frac{\beta}{\frac{\sum\left(\mathrm{Y}_{\mathrm{i}}-\hat{\mathrm{Y}}_{\mathrm{i}}\right)^{2}}{(\mathrm{n}-2) \sum\left(\mathrm{X}_{\mathrm{i}}-\overline{\mathrm{X}}\right)^{2}}}
$$

(2)

where,

$t$ is distributed like students' $t$ with $n-2$ degrees of freedom and $n$ is the sample size (Frei, 2014). 
Appendix B: Trend Analysis of Conflict Data

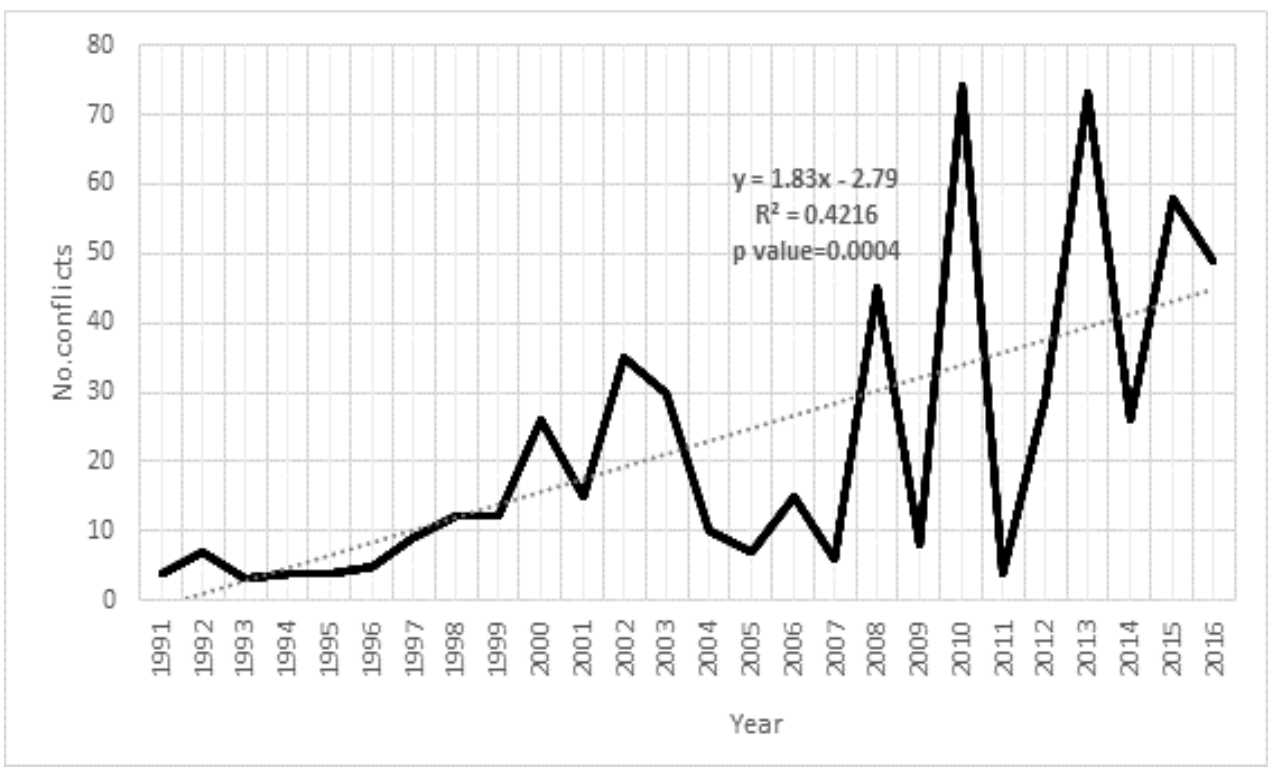

Figure A: The frequency of major conflicts in Ethiopia by types of actors 19912016

Source: Authors' computations from Armed Conflict Location and Event Data Project (ACLED) Version 5 and Abbink (2006). 


\section{Moving Average}

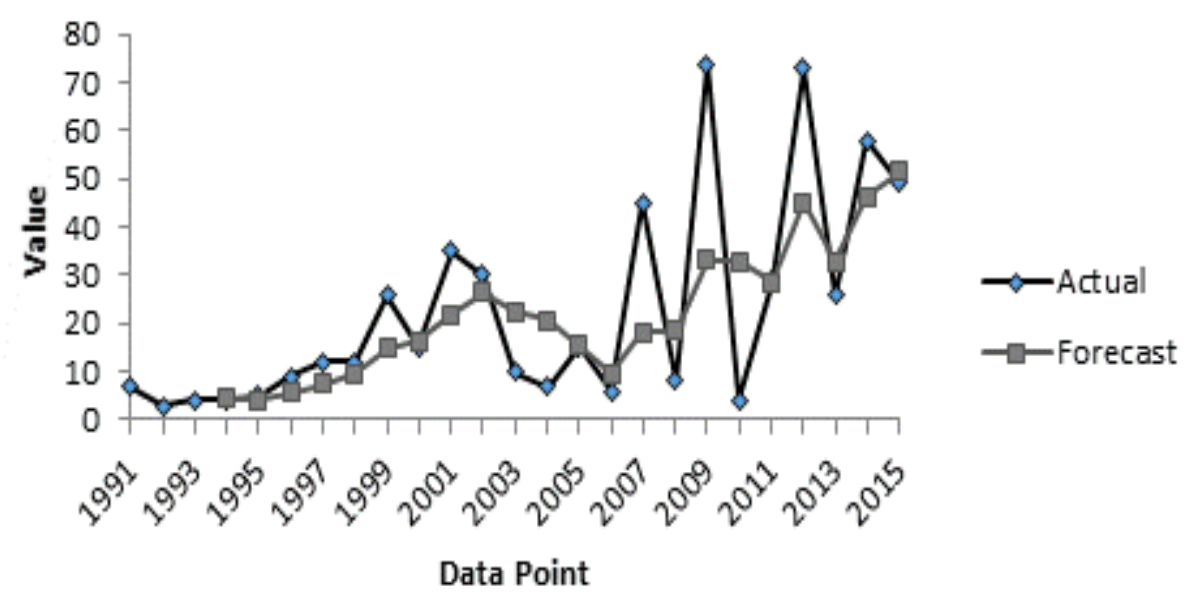

Figure B: The Moving Average Trend in frequency of Ethnic conflicts in Ethiopia 1991-2016

Source: Authors' computations from Armed Conflict Location and Event Data Project (ACLED) Version 5 and Abbink (2006). 